\title{
Perancangan Sistem Informasi Unit Kesehatan Sekolah Menggunakan Model Prototipe
}

\author{
Imam Sutoyo \\ Universitas Bina Sarana Informatika Jakarta \\ e-mail: imam.ity@bsi.ac.id
}

\begin{abstract}
Unit Kesehatan Sekolah (UKS) yang bertugas memberikan pelayanan kesehatan khususnya terhadap siswa, telah menjadi bagian vital dari operasional sebuah sekolah. Oleh karena itu, pelayanan pada UKS perlu ditingkatkan efektifitas dan efisiensinya. Salah satu permasalahan yang menghambat kinerja UKS adalah pemrosesan data dan informasi secara manual dikarenakan belum adanya sistem yang terkomputerisasi. Penelitian ini bertujuan untuk merancang sistem informasi UKS yang akan menggantikan seluruh prosedur manual sehingga kinerja UKS dapat ditingkatkan efektifitas dan efisiensinya. Untuk perancangannya digunakan Unified Modelling Language (UML) dan Entity Relationship Diagram (ERD), sedangkan metode pengembangan sistem yang digunakan adalah model prototipe.
\end{abstract}

Keywords: Entity Relationship Diagram, Prototipe, Sistem Informasi, Unified Modelling Language, Unit Kesehatan Sekolah

\begin{abstract}
The School Health Unit (UKS), which is tasked with providing health services, especially to students, has become a vital part of the operations of a school. Therefore, the effectiveness and efficiency of services at UKS need to be improved. One of the problems that hinders UKS performance is manual processing of data and information due to the absence of a computerized system. This study aims to design a UKS information system that will replace all manual procedures so that UKS performance can be improved in terms of effectiveness and efficiency. For the design, Unified Modeling Language (UML) and Entity Relationship Diagram (ERD) are used, while the system development method used is a prototype model.
\end{abstract}

Keywords: Entity Relationship Diagram, Prototype, Information System, Unified Modelling Language, School Health Unit

\section{PENDAHULUAN}

Pelayanan kesehatan merupakan kegiatan yang vital di lembaga apapun karena masalah kesehatan berkaitan dengan kehidupan seseorang. Di sekolah, dibentuk Unit Kesehatan Sekolah (UKS) yang bertugas memberikan pelayanan kesehatan kepada seluruh civitas akademika sekolah, khususnya siswa. Melalui UKS diharapkan sekolah dapat lebih memperhatikan kesehatan para peserta didiknya (Fadly \& Pramudita Faddila, 2020).

Salah satu permasalahan pokok pada UKS adalah pengolahan data dan informasi yang masih menggunakan prosedur-prosedur manual dan aplikasi spreadsheet, yakni hanya menggunakan catatan pada buku maupun menggunakan Ms Excel. Sekolah yang menjalankan program UKS, pengelolaan datanya masih dilakukan secara manual, sehingga dapat membuat pencatatan yang kurang akurat (Fadly \& Pramudita Faddila, 2020). Pengelolaan data pasien masih bersifat manual sehingga pelayanan pasien masih terbatas dan database rekam pasien belum tertata dengan baik (Kholid Alghofari et al., 2021).
Kegiatan seperti mengelola data pasien, rekam medis pasien, data dokter, masih dilakukan cara manual dan membutuhkan waktu yang cukup lama dalam pencarian data pasien (Pamungkas, 2020).

Solusi dari permasalahan-permasalahan tersebut adalah dengan membangun Sistem Informasi UKS. Dengan diterapkannya sistem informasi, maka data pasien, data obat, dan data rekam medis pasien dapat terorganisir dengan baik sehingga dapat dihasilkan informasi yang cepat dan akurat sehingga akan meningkatkan efektifitas dan efisiensi pelayanan UKS.

\section{METODOLOGI PENELITIAN}

Model yang digunakan adalah Prototipe. Model Prototipe mengutamakan pembuatan software yang siap pakai bagi pelanggan dibandingkan membuat dokumentasi (Ganpatrao Sabale \& Dani, 2012). Model Prototipe sangat potensial untuk menghasilkan produk berkualitas tinggi karena memungkinkan keterlibatan pengguna yang tinggi selama proses pengembangan (Norhalim \& Ismail, 2020). Model

http://ejournal.bsi.ac.id/ejurnal/index.php/paradigma/issue/archive/ 145 
Prorotipe memiliki 3 tahap, yaitu mendengarkan pelanggan, membuat mock up, merevisi mock up berdasarkan permintaan pelanggan (Syafril et al., 2021).

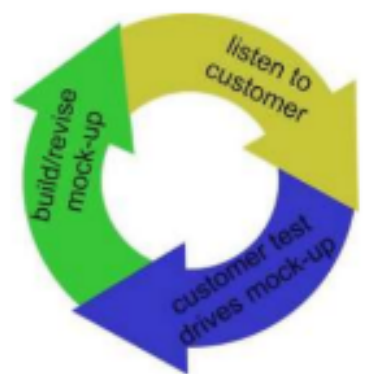

Sumber: (Syafril et al., 2021)

Gambar 1. Model Prototipe

a. Mendengarkan pelanggan

Pada tahap ini, kebutuhan pelanggan didengarkan. Hasilnya dituangkan dalam bentuk rancangan menggunakan UML dan ERD.

b. Membuat mock up

Pada tahap ini, desain diimplementasikan. Untuk backend menggunakan MySQL dan PHP sedangkan untuk frontend menggunakan framework Bootstrap.

c. Merevisi mock up

Pada tahap ini, sistem direvisi atau diupdate menyesuaikan keinginan dan kebutuhan pelanggan.

\section{HASIL DAN PEMBAHASAN}

\section{Mendengarkan pelanggan}

Tahap pertama adalah mendengarkan apa saja yang dibutuhkan oleh pelanggan, yaitu petugas UKS. Petugas UKS menjelaskan data-data apa saja yang perlu disimpan dan diolah. Kebutuhan ini selanjutnya kami tuangkan dalam bentuk diagram use case.

\section{Diagram usecase}

Diagram use case menggambarkan seluruh kegiatan yang dapat dilaksanakan oleh aktor pada sistem.

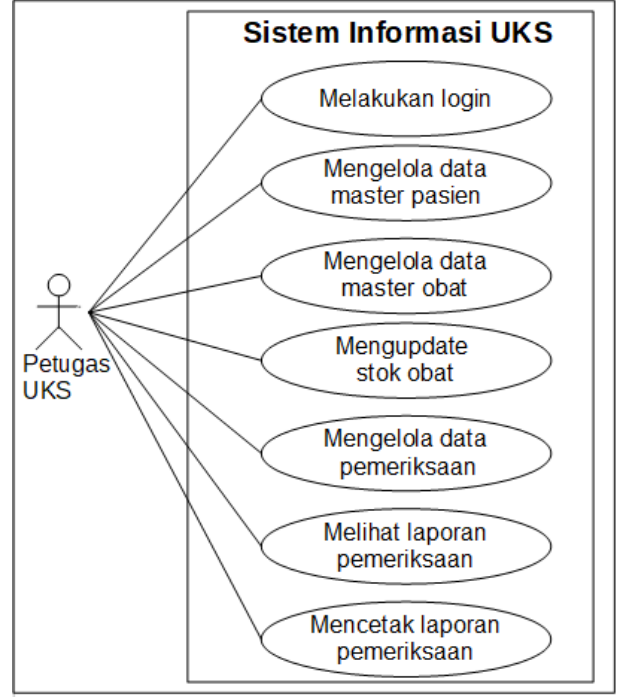

Sumber: (Sutoyo, 2021)

Gambar 2. Use Case Petugas UKS

\section{Diagram activity}

Diagram activity digunakan untuk menggambarkan alur tahapan secara sistematis seluruh kegiatan yang dilakukan aktor terhadap sistem.

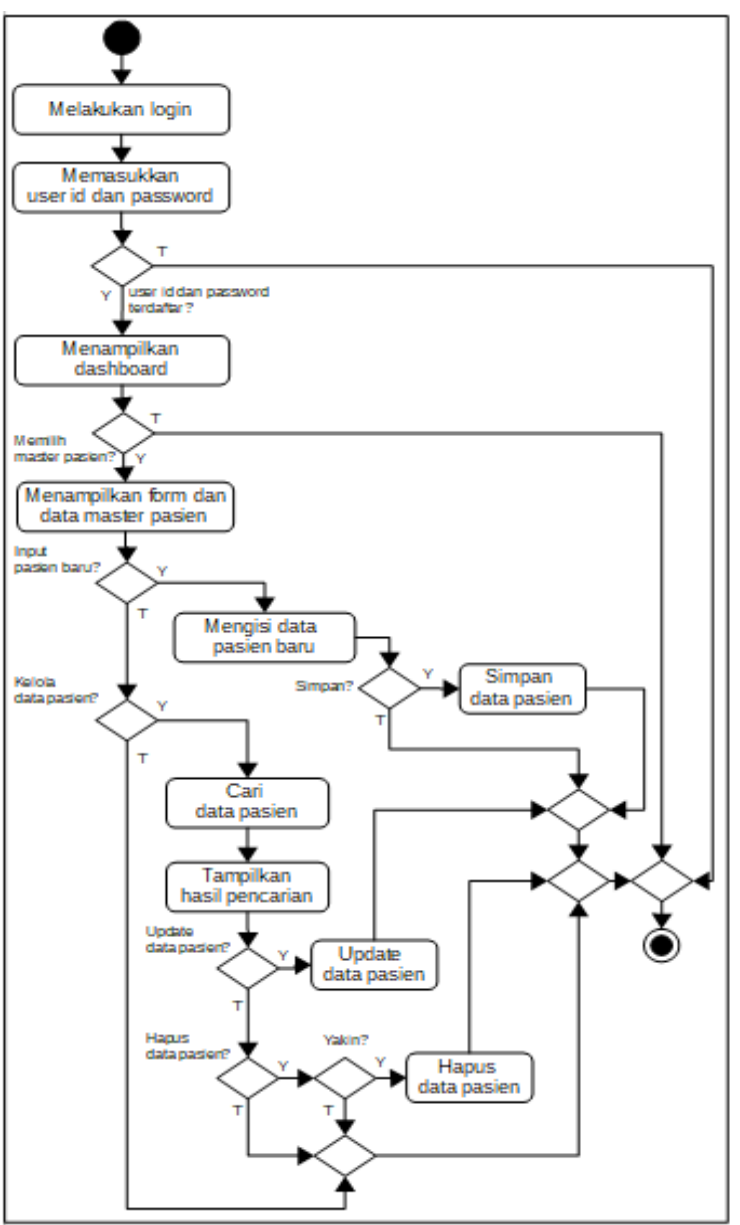

Sumber: (Sutoyo, 2021)

Gambar 3. Activity Pengelolaan Data Master Pasien 
Petugas mulai dengan memasukkan user id dan password. Jika valid maka akan tampil dashboard. Dashboard berisi rekapitulasi dan chart yang menggambarkan informasi secara global dari data tersimpan. Setelah memilih menu master pasien, maka akan ditampilkan form dan tabel berisi data pasien berikut menu untuk mengupdate dan menghapus record pasien.

Pada tahap awal maka data pasien bisa diimport dari data siswa yang dimiliki tata usaha sekolah. Data dari tata usaha sekolah yang biasanya berupa file Ms Excel diubah ke format CSV terlebih dahulu kemudian file CSV ini bisa diimport ke database. Jika ada penambahan siswa maka data siswa baru tersebut bisa ditambahkan melalui formulir pasien baru.

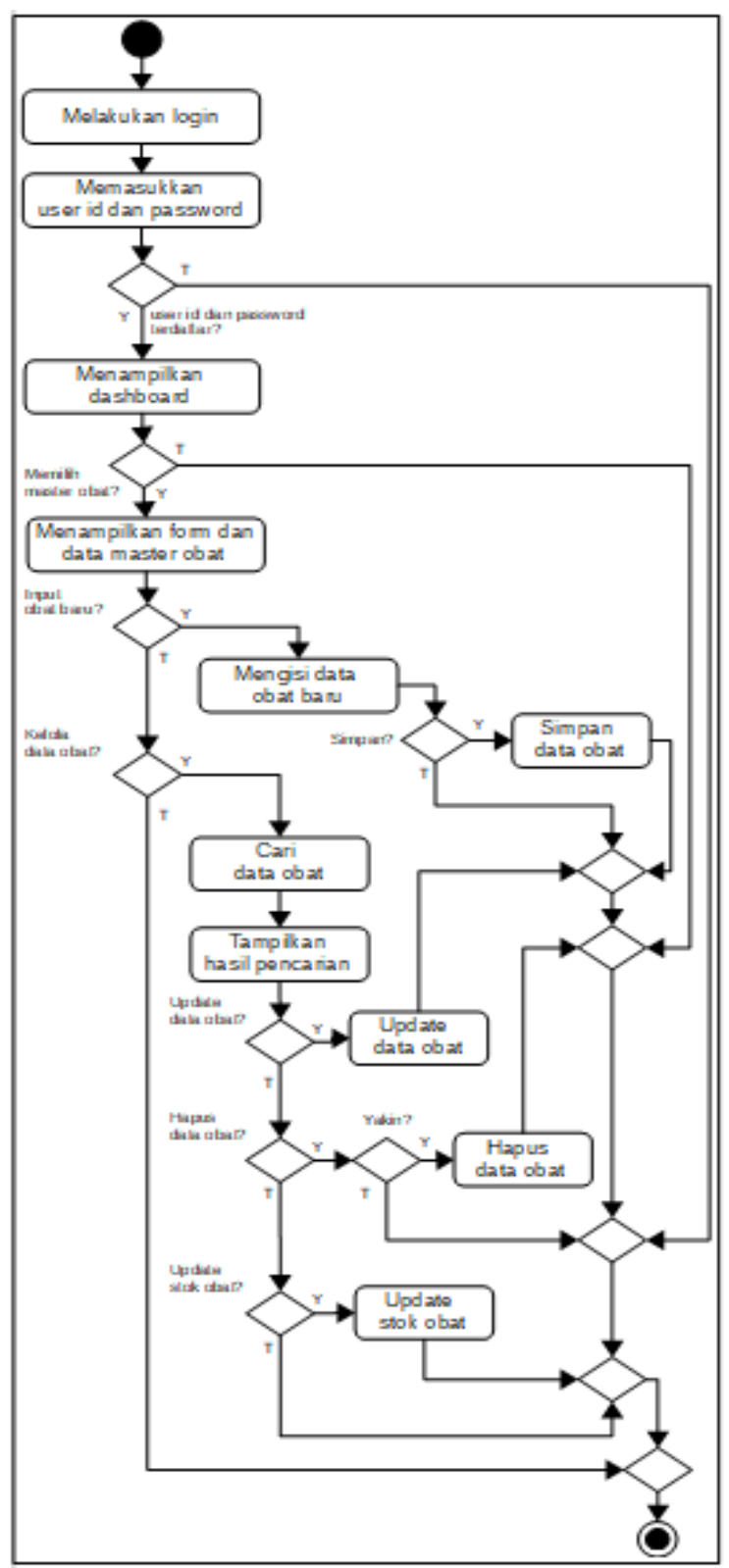

Sumber: (Sutoyo, 2021)

Gambar 4. Activity Pengelolaan Data Master Obat
Setelah berhasil login dan memilih menu master obat, maka akan ditampilkan form dan tabel berisi data obat berikut menu untuk mengupdate dan menghapus record, dan juga untuk mengupdate stok obat. Untuk obat yang baru masuk bisa diinput berikut jumlah stoknya. Untuk obat yang sudah ada bisa diupdate stoknya dengan cara dicari terlebih dahulu record obat tersebut menggunakan fitur pencarian berdasarkan kode obat atau namanya baru kemudian klik menu update stok untuk mengupdate stoknya.

Untuk kesederhanaan implementasi sistem, maka peralatan kesehatan yang menjadi inventaris UKS seperti alat uap, termometer, dan sebagainya bisa dimasukkan ke dalam data master obat ini. Jika data peralatan kesehatan tersebut ingin dipisah maka bisa dibuat menjadi tabel master inventaris tersendiri dengan prosedur yang persis seperti yang digambarkan pada diagram activity master obat ini.

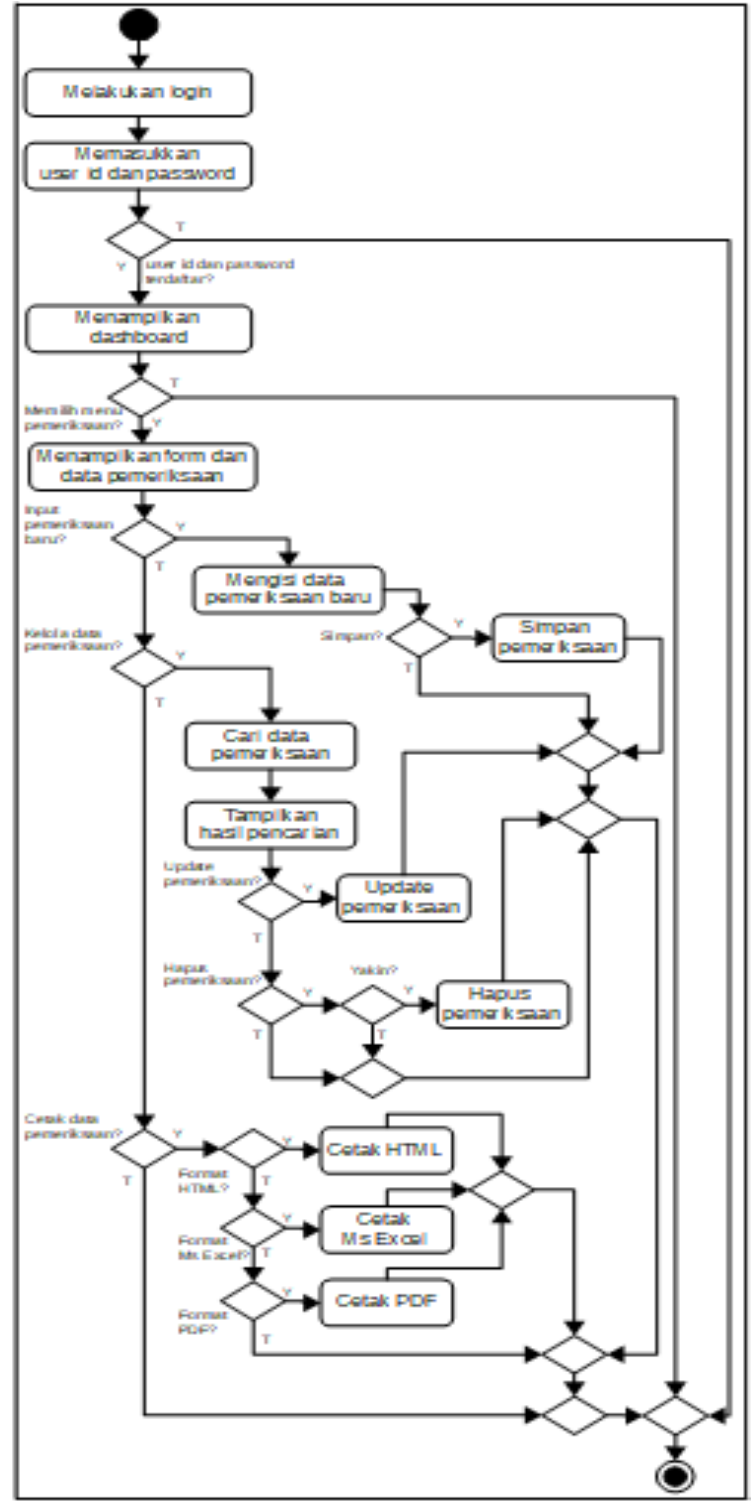

Sumber: (Sutoyo, 2021)

Gambar 5. Activity Pengelolaan Data Pemeriksaan 
Setelah berhasil login dan memilih menu transaksi pemeriksaan, maka akan ditampilkan form dan tabel berisi data transaksi pemeriksaan berikut menu untuk mengupdate dan menghapus record pemeriksaan.

Selain itu, ditampilkan juga laporan pemeriksaan yang berisi informasi lengkap seluruh pemeriksaan yang telah diinput datanya. Laporan ini bisa dicetak dalam tiga format sesuai kebutuhan, yaitu HTML, Ms Excel, dan PDF. Format HTML adalah format native untuk ditampilkan di situs web. Format Ms Excel biasa digunakan untuk pengolahan data lanjutan dan juga untuk arsip softcopy. Format PDF adalah format universal, bisa untuk ditampilkan di situs web, arsip softcopy, maupun untuk dicetak sebagai hardcopy.

\section{Entity Relationship Diagram (ERD)}

ERD merupakan diagram yang dapat digunakan untuk menggambarkan rancangan skema database. ERD menghubungkan semua tabel, dengan kata lain menghubungkan semua entitas yang memungkinkan kita untuk mengekstrak data yang diperlukan menggunakan query SQL (Mathias et al., 2020).

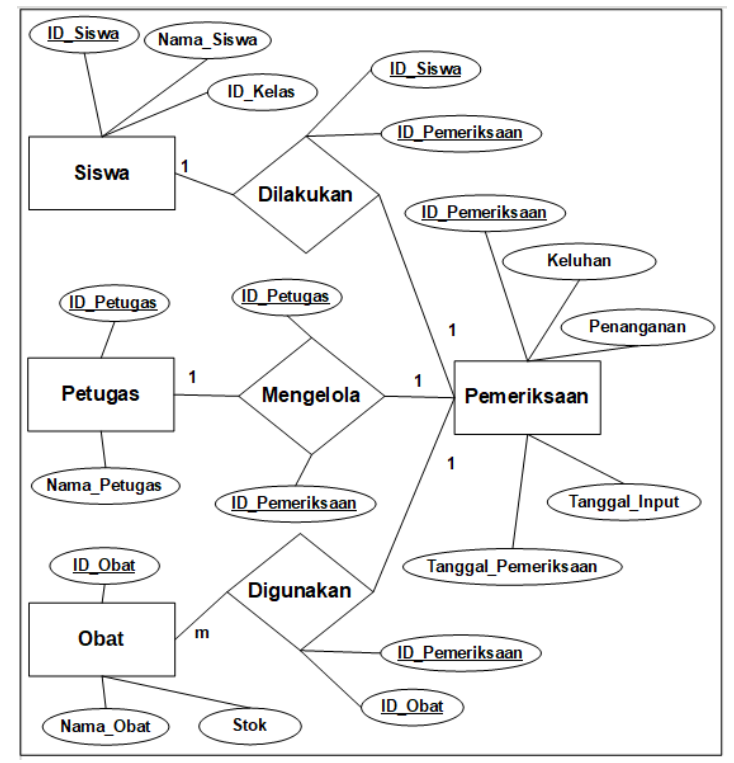

Sumber: (Sutoyo, 2021)

Gambar 6. Rancangan ERD Database

Skema memiliki empat entitas, yaitu Siswa, Petugas, Obat, dan Pemeriksaan. Siswa adalah entitas yang akan dicatat data pemeriksaannya menjadi rekam medis. Petugas adalah entitas yang melakukan pemeriksaan dan menginput serta mengelola record pemeriksaan. Obat adalah entitas yang akan digunakan pada kegiatan pemeriksaan. Ketiganya merupakan entitas yang fisiknya ada dan akan diimplementasikan menjadi tabel master di database.

Entitas Pemeriksaan adalah entitas yang bersifat konsep yang fisiknya tidak ada. Pemeriksaan akan berisi record transaksi yang setiap recordnya akan berisi data pemeriksaan seorang siswa. Entitas ini akan diimplementasikan menjadi tabel transaksi di database.

\section{Membuat mockup}

Tahapan kedua dari prototipe adalah membuat mockup berdasarkan rancangan UML dan ERD.

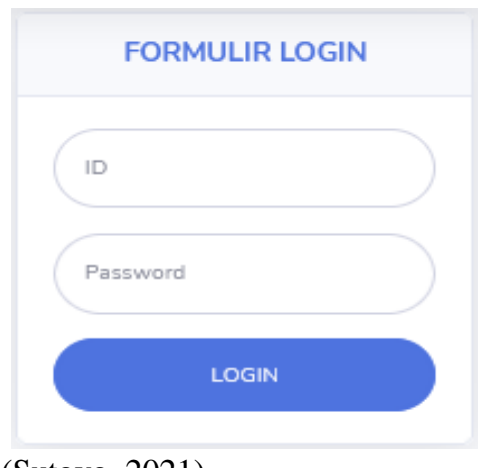

Sumber: (Sutoyo, 2021)

Gambar 7. Rancangan Formulir Login

Gambar 7 adalah rancangan formulir login Petugas. Petugas login menggunakan akun yang berisi ID dan Password.

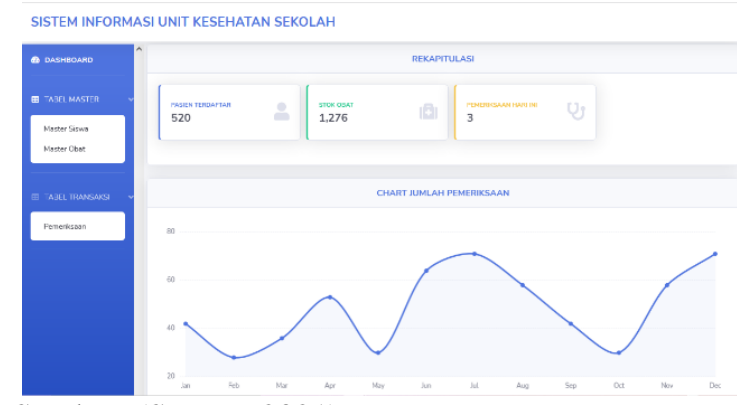

Sumber: (Sutoyo, 2021)

Gambar 8. Rancangan Dashboard

Gambar 8 adalah rancangan dashboard. Dashboard berisi informasi global berupa rekapitulasi dan chart yang menggambarkan jumlah transaksi pemeriksaan dalam periode bulan selama satu tahun ajaran.

\section{FORMULIR INPUT MASTER SISWA}

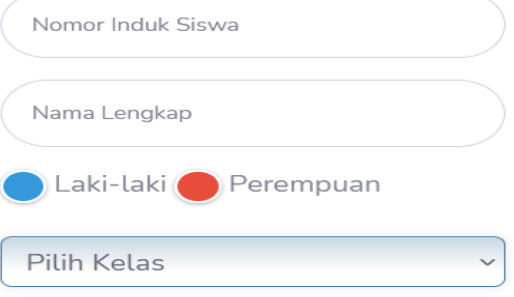

\section{SIMPAN}

Sumber: (Sutoyo, 2021)

Gambar 9. Formulir Input Siswa Baru 
Gambar 9 adalah rancangan formulir input siswa yang akan menjadi pasien dari UKS. Formulir ini digunakan untuk menginput siswa baru yang belum terdaftar menjadi pasien UKS karena untuk siswa lama sudah diimport datanya di awal tahun ajaran.

\begin{tabular}{|c|c|c|c|c|c|c|}
\hline \multicolumn{7}{|c|}{ ADMINISTRASI MASTER SISWA } \\
\hline \multicolumn{7}{|c|}{ Search: } \\
\hline No. ${ }^{\star}$ & Menu $\neq$ & ID Siswa $\neq$ & Nama Siswa & 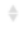 & $\mathrm{JK} \neq$ & Kelas \\
\hline 1 & ட゙す & MTS-744 & Muhammad & & $\mathrm{L}$ & MTS-1-A \\
\hline 2 & ட゙も & MTS-843 & Maryam & & $\mathrm{P}$ & MTS-1-B \\
\hline howing 1 & to 2 of $2 \mathrm{en}$ & & & \multicolumn{2}{|c|}{ Previous } & Next \\
\hline
\end{tabular}

Sumber: (Sutoyo, 2021)

Gambar 10. Rancangan Administrasi Master Siswa

Gambar 10 adalah rancangan untuk mengelola data master siswa. Jika ada data siswa yang salah bisa diupdate disini. Untuk siswa yang sudah keluar bisa dihapus datanya disini.

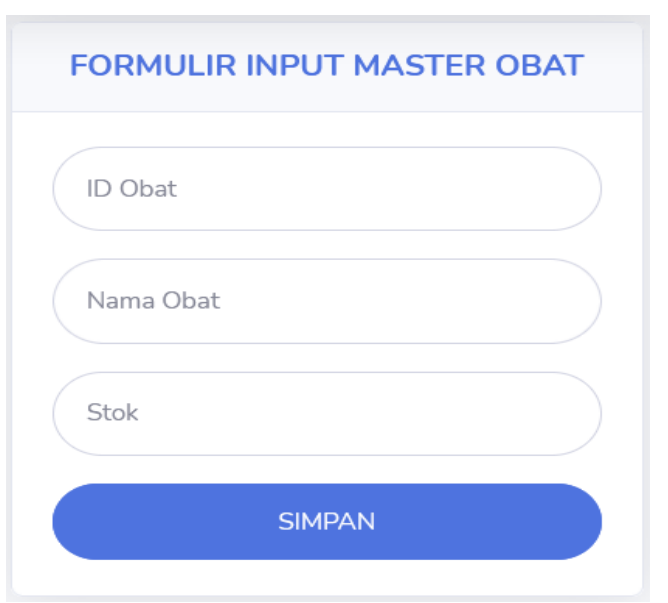

Sumber: (Sutoyo, 2021)

Gambar 11. Formulir Input Data Obat

Gambar 11 adalah rancangan untuk menginput data obat. Setiap obat yang masuk disimpan berikut jumlah stok obat tersebut.

Sumber: (Sutoyo, 2021)

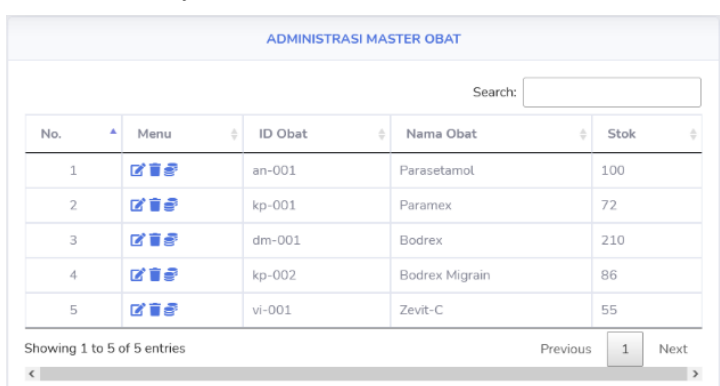

Gambar 12. Rancangan Administrasi Master Obat

Gambar 12 adalah rancangan untuk mengelola master obat. Data obat yang sudah diinput akan tampil disini berikut stoknya. Jika ada kesalahan atau perubahan maka data obat bisa diupdate disini. Data obat yang tidak diperlukan lagi bisa dihapus disini. Untuk tambahan stok obat juga bisa diinput disini.

Sumber: (Sutoyo, 2021)

Gambar 13. Rancangan Formulir Update Stok Obat

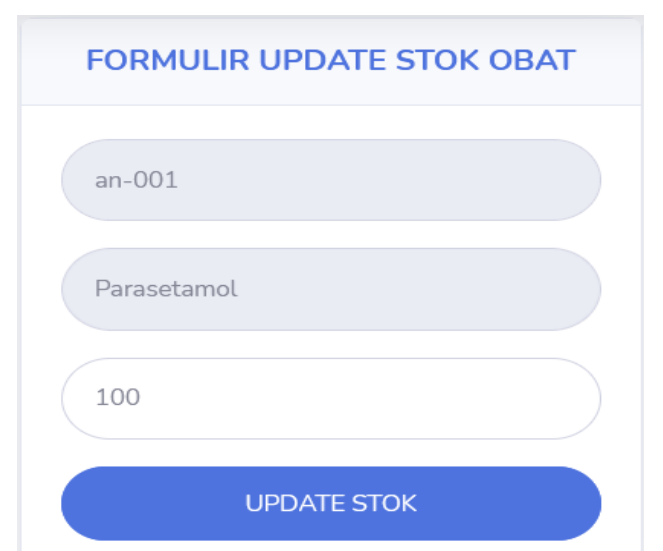

Gambar 13 adalah rancangan formulir untuk mengupdate stok obat. Untuk kode obat dan nama obat dibuat readonly karena disini hanya stok yang akan diupdate datanya. Jumlah stok yang diinput via formulir ini selanjutnya akan ditambahkan ke stok obat tersebut yang tersimpan di database.

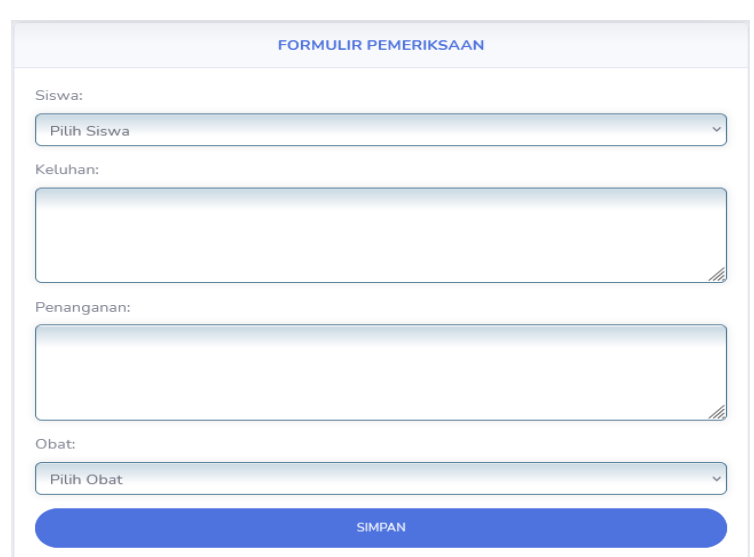

Sumber: (Sutoyo, 2021)

Gambar 14. Rancangan Formulir Pemeriksaan

Gambar 14 adalah rancangan formulir pemeriksaan untuk menginput data-data pemeriksaan pasien UKS. Pertama, siswa yang menjadi pasien dicari kemudian dipilih dari daftar siswa pada elemen inputan select yang sudah terisi dengan merujuk ke tabel master siswa. Jika siswa tersebut ternyata belum ada maka bisa ditambahkan terlebih dahulu melalui formulir pasien baru.

Kedua, keluhan-keluhan yang dialami oleh pasien dicatat dengan detail. Ketiga, dilakukan penanganan oleh petugas UKS. Penanganan ini pun diinput datanya melalui form pemeriksaan ini. Keempat, ditentukan obat yang akan diberikan kepada pasien. Obat yang diberikan dipilih dari daftar obat pada elemen inputan select yang sudah terisi dengan merujuk ke tabel master obat. 


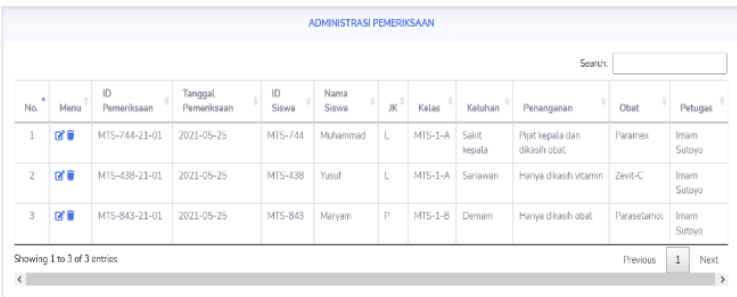

Sumber: (Sutoyo, 2021)

Gambar 15. Rancangan Administrasi Pemeriksaan

Gambar 15 adalah rancangan untuk mengelola data transaksi pemeriksaan. Petugas bisa melakukan update data pemeriksaan atau menghapus record pemeriksaan melalui menu yang tersedia.

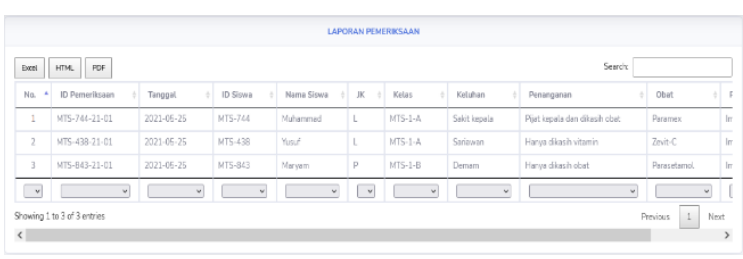

Sumber: (Sutoyo, 2021)

Gambar 16. Rancangan Laporan Pemeriksaan

Gambar 16 adalah rancangan laporan pemeriksaan. Laporan tersebut berisi seluruh pemeriksaan yang siap dicetak dalam bentuk tiga format, yaitu HTML, Ms Excel, dan PDF.

\section{Merevisi mockup}

Tahapan terakhir adalah merevisi mockup berdasarkan masukan dari petugas UKS. Misalnya, petugas meminta agar tampilan dioptimalkan untuk handphone. Maka tabel horizontal pun diubah menjadi tabel vertikal sesuai tampilan handphone. Sesuai dengan prinsip prototipe maka revisi ini berjalan selama sistem digunakan.

\section{KESIMPULAN}

Model prototipe terbukti efektif untuk membangun sistem informasi UKS secara cepat dan sesuai dengan kebutuhan petugas UKS. Hal ini sesuai dengan prinsip prototipe untuk merevisi sistem sesuai kebutuhan pelanggan dengan selalu mendengarkan pelanggan. Sistem ini memadai untuk menggantikan seluruh prosedur manual pengolahan data UKS. Penelitian dapat dikembangkan dengan merancang sistem yang dapat diakses oleh seluruh stakeholder sekolah, baik pihak internal yaitu guru dan manajemen sekolah maupun eksternal yaitu orang tua atau wali siswa dan komite sekolah.

\section{REFERENSI}

Fadly, F., \& Pramudita Faddila, S. (2020). Rancangan Basis Data Sistem Informasi Usaha Kesehatan Sekolah. Jurnal Ilmu Komputer Dan Teknologi Informasi, 5(2), 49-55.

Ganpatrao Sabale, R., \& Dani, A. (2012). Comparative Study of Prototype Model For Software Engineering With System Development Life Cycle. IOSR Journal of Engineering (IOSRJEN), 2(7), 21-24. www.iosrjen.org

Kholid Alghofari, A., Munawir, H., Sufa, M. F., \& Arifin, A. L. M. (2021). Sistem Informasi Manajemen Klinik Imam Syuhodo PKU Muhammadiyah Cabang Blimbing Berbasis Website. The 13th University Research Colloqium , 27-35.

Mathias, S. G., Schmied, S., \& Grossmann, D. (2020). An Investigation on Database Connections in OPC UA Applications. Procedia Computer Science, 170, 602-609. https://doi.org/10.1016/j.procs.2020.03.132

Norhalim, N., \& Ismail, A. (2020). An Early Development Process of an Augmented Reality-Based Healthy Diet Tool Prototype. International Journal of Multimedia and Recent Innovation, 2(2), 96-101. https://doi.org/10.36079/lamintang.ijmari0202.133

Pamungkas, A. (2020). Rancang Bangun Sistem Informasi Pelayanan Kesehatan Untuk Rekam Medis Rawat Jalan Pada Klinik Pratama Afiyah Medika Berbasis Desktop. Journal Of Artificial Intelligence And Innovative Applications, 1(2), 56-60.

http://openjournal.unpam.ac.id/index.php/infor matika56

Sutoyo, I. (2021). Laporan Akhir Penelitian: Perancangan Sistem Informasi Unit Kesehatan Sekolah Menggunakan Model Prototipe.

Syafril, S., Asril, Z., Engkizar, E., Zafirah, A., Agusti, F. A., \& Sugiharta, I. (2021). Designing prototype model of virtual geometry in mathematics learning. Journal of Physics: Conference Series.

\section{PROFIL PENULIS}

Imam Sutoyo, M.Kom, lulusan S2 Ilmu Komputer STMIK Nusa Mandiri, mengajar di Universitas Bina Sarana Informatika (2008 - sekarang). 